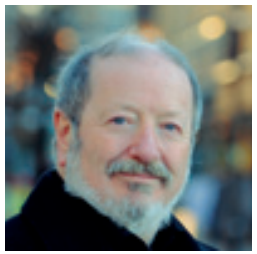

\title{
Når tiden og legen ikke strekker til...
}

\section{Det moderne mennesket som kunde, forbruker og pasient.}

Stadig flere sier og opplever at de er utslitte og utbrente. De har ikke lenger overskudd og kraft til å takle sin egen hverdag. Det skjer i en tid da vi beviselig aldri har vært færre timer på jobb, aldri har hatt en bedre materiell levestandard og aldri tidligere hatt så mye fritid og muligheter for rekreasjon. Det paradoksale er derfor at når folk sier at de er slitne, ikke takler presset og ikke får hvilt skikkelig tross tilgang både på fritid og hjelpemidler, så er det ikke tomt prat, men en reell opplevelse for den enkelte.

Ser vi på arbeidshverdagen til folk flest, vil vi se at antall timer vi tilbringer på jobben er færre enn for noen tiår siden. Arbeidet er for stadig flere heller ikke lenger fysisk slitsomt og krevende. Arbeidet er blitt annerledes, kravene som stilles er i liten grad avhengig av den ansattes fysiske kapasitet. Det stilles større krav til hodet enn til muskler og skjelett.

Mens rygg- og muskelslitasje før var hovedgrunn til at folk i arbeidslivet var utslitt, og at slitasjen kunne relateres til yrket, fikk tusenvis i løpet av 1980- og 90årene diagnosen fibromyalgi - en for meg diffus og uforklarlig lidelse. Nå lider folk av utbrenthet - like diffust og like ødeleggende for den som rammes. Og det er klare indikasjoner på at fritidens konsumering er vel så belastende for mange som lønnet arbeid.

At folk var og er utslitte, at kroppen sier fra, er reelt nok - selv om det trolig kan tilskrives mer psyke enn fysikk, fordi mange som har fått disse lidelsene ikke har hatt fysisk harde jobber. Mange hadde faktisk bare deltidsstillinger da fibromyalgi gjorde dem uføre. Det ble snakket mye om dobbeltarbeidende kvinner, siden kvinnene var overrepresentert blant dem som ble diagnostisert. Sikkert en reell problemstilling, men det ligger så mange paradokser i dette at det er all grunn til å se etter andre løsninger og problemstillinger.

En fremtidsforsker ble spurt om hvem som er fremtidens tapere og vinnere. Hun svarte at taperne er de som blir ofre for kjøpesentrene, kommersialiseringen av livene våre, de som konsumerer opplevelser og sine liv. Vinnerne blir de som kan skjerme seg mot de samme trendene, de som finner rom til menneskelig fellesskap der innholdet er refleksjon, dialog og et aktivt liv med og for andre. En stor del av befolkningen generelt, men kanskje ungdom spesielt, lever av å konsumere opplevelser og materielle goder. Min sambygding i Stange, tidligere statsminister Odvar Nordli, uttalte at «markedskreftene tyranniserer hodene våre». En representant for de samme markedskreftene uttalte at markedskampen om folks fritid er knallhard. Slike uttalelser gjør at vi bør reflektere over Oscar Wildes ord: Den som kun kjenner prisen på alt, kjenner ikke verdien av noe. Så blir vi altså et folk som konsumerer mer enn vi produserer, og det synes som om det ikke finnes grenser for hva vi kan konsumere.

Også inne i mitt hode danner virkeligheten holdninger som jeg trenger å vurdere innholdet av. For jeg er nemlig blitt klar til å konsumere dere leger! For, må vite, dere finnes for å tilfredsstille alle mine forventninger om at min helse er legens ansvar.
I en individualisert verden blir jeg mer kunde enn pasient, og da må jeg kunne forvente å bli frisk, da det er det jeg betaler for. Men så sniker det seg inn noen underlige tanker når jeg sitter på venteværelset til Kjell Petter, fastlegen min. Tenk hvor enkel helsedefinisjonen var i Vallsetbygda i 1930årene. Da sa man at «den som itte skrik høgt, hell blør stygt, er itte sjuk». Jeg hører ingen skrik og ser ikke noe blod på venteværelset, jeg ser mennesker som like godt kunne sittet på kantina på jobben.

Habermas sa at etikk er å behandle mennesker som mennesker. Men hvordan blir vi når mennesker blir behandlet som kunder? Jo, da tror jeg at vi blir kunder og forbrukere - og da blir vi kravstore og krever våre forbrukerrettigheter. $\mathrm{Og}$, går det an å behandle en lege som et menneske? Jeg skal jo tross alt konsumere legens tjenester, og jeg betaler for det! I legerollen ligger det forventninger om styrke og autoritet. Jeg undrer meg såpass at mitt spørsmål blir: Kanskje det er de sterke som trenger støtte, fordi det koster så mye å være sterk hele tiden? Min lodd blir da å spørre hvordan Kjell Petter har det, som mitt lille bidrag til å være medmenneske og ikke konsument av den grenseløse helseforventningen som er skapt $\mathrm{i}$ vårt samfunn.

Vi må være med på utviklingen, fremskrittene og all innovasjon. Til det sier jeg at hvis disse trekkene er den eneste veien fremover, ja, da skal jeg ingen steder!

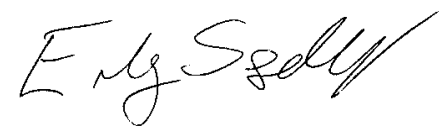

\section{I neste nummer:}

Utdanningsnummeret

Global helse i medisinstudiet

- Ferdighetssenteret ved Universitetet i Oslo
Forskningsjuks

Klinisk undersøkelse på nett

Finanskrisen og helsen 